\title{
Au-Pd AND Bi-Se BEARING PYRITE AND CHALCOPYRITE FROM THE BUCHIM COPPER MINE, EASTERN MACEDONIA
}

\author{
Au-Pd IN Bi-Se PIRITI IN HALKOPIRITI IZ RUDNIKA BAKRA, \\ BUĆIM, VZHODNA MAKEDONIJA
}

\author{
Todor Serafimovski ${ }^{1 *}$, Tadej Dolenec ${ }^{2}$, Goran Tasev ${ }^{1}$, Dalibor Serafimovski ${ }^{3}$, \\ Nastja Rogan Smuc², Matej Dolenec ${ }^{2}$ \\ ${ }^{1}$ University "Goce Delcev"- Stip, Faculty of Natural and Technical Sciences, Institute of Geology, str. Bul. Goce Delcev No.89, \\ 2000 Stip, Republic North Macedonia \\ ${ }^{2}$ Department of Geology, Faculty of Natural Sciences and Engineering, University of Ljubljana, Aškerčeva 12, 1000 Ljubljana, Slovenija
}

Prejem rokopisa - received: 2019-12-24; sprejem za objavo - accepted for publication: 2020-10-16

doi: $10.17222 /$ mit.2019.306

\begin{abstract}
In the Buchim porphyry copper deposit, we determined several representative rare mineral phases, comprising metals from the gold-palladium group as well as those from the bismuth-selenium (Cu-Bi-Se-Te-As) group. The bismuth-selenium rare mineral phases are represented by new rare mineral phases in the Buchim porphyry copper deposit, bismuthinite, galenobismutite, krupkaite, friedrichite, emplectite, laitakarite and native bismuth as well as mineral phases of gold-palladium, including gold and palladium with their elemental mixtures. It should be stressed that both types of rare mineral phases were determined in pyrite and chalcopyrite from major ore paragenesis in the Buchim deposit. The bismuth-selenium mineral phases were related to the major quartz-pyrite-chalcopyrite paragenesis, while the gold-palladium phases were related to a slightly higher temperature, oxido-sulphide parageneses such are magnetite-pyrite-chalcopyrite (Mt-Py-Cp) and pyrite-chalcopyrite (Py-Cp).
\end{abstract}

Keywords: ore minerals, Au-Pd phases, rare Bi-Se mineral phases, Buchim mine

Na območju bakrovega porfirskega rudišča Bućim smo določili več reprezentativnih redkih mineralnih faz, ki vsebujejo kovine iz skupine zlato-paladij in nadalje iz skupine bizmut-selen (Cu-Bi-Se-Te-As). Redke mineralne faze bizmut-selen so predstavljene z novimi redkimi mineralnimi fazami, in sicer, bizmutinita, galenobismutita, krupkaita, friedrichita, emplektita, laitakarita in naravnega bizmuta, pa tudi mineralnih faz zlata-paladija, vključno z zlatom in paladijem iz njihove elementarne mešanice. Poudariti je treba, da sta bili obe vrsti redkih mineralnih faz določeni v piritu in halkopiritu iz glavne rude na območju Bućima. Mineralne faze bizmut-selen so bile povezane z glavno paragenezo kremen-pirit-halkopirit, medtem ko so mineralne faze zlato-paladij povezane $\mathrm{z}$ nekoliko višjo temperaturo, torej $\mathrm{z}$ oksidno-sulfidno paragenezo, ki jo definirajo magnetit-pirit-halkopirit (Mt-Py-Cp) in pirit-halkopirit (Py-Cp).

Ključne besede: rudni minerali, faze Au-Pd, redke mineralne faze Bi-Se, rudnik Bućim

\section{INTRODUCTION}

The Buchim porphyry copper-type deposit is located in eastern central Macedonia, $10 \mathrm{~km}$ west of the town of Radovis. It is the only deposit of this type in Macedonia that is currently being exploited and producing copper and significant amounts of gold as a by-product. The mine started production in 1980 and produces four million tons of ore annually, with $0.25 \% \mathrm{Cu}, 0.27 \% \mathrm{Au}$ and $1 \mathrm{~g} / \mathrm{t} \mathrm{Ag}$. Estimated reserves are approximately 100 million tons of low grade $\mathrm{Cu}-\mathrm{Au}$ ores with some $\mathrm{Ag}$ and $\mathrm{Mo}$ and includes primary (the most important $\mathrm{Cu}-\mathrm{Au}$ resources) as well as secondary (related to the zone of oxidation-cementation enrichment) and mixed types of ores. The mineralisation of the Buchim ore deposit is related to tertiary sub-volcanic intrusions of andesite and latite in a host of Pre-Cambrian gneisses and amphibolites. ${ }^{1,2}$

The paragenesis of this deposit was studied by $\mathrm{M}$. Pavičević and S. Rakić, ${ }^{3}$ V. Čifliganec, ${ }^{2}$ T. Serafimovski et $\mathrm{al}^{4}{ }^{4}$ and others. Besides the basic ore paragenesis (py-

*Corresponding author's e-mail:

todor.serafimovski@ugd.edu.mk (Todor Serafimovski) rite, chalcopyrite, magnetite, bornite and enargite), Bi-Se mineral phases and especially Au-Pd mineral phases were also determined. R. Petrunov et al. ${ }^{5}$ published preliminary microscopic and microprobe data of the occurrence of the platinum group elements (PGEs) within the Buchim porphyry copper deposit for the first time. An increased content of Pd as well as palladium-mineralisation (PGM-Platinum Group of Minerals) was established in the $\mathrm{Cu}-\mathrm{Au}$ ores of the deposit in Buchim, Macedonia. Thus, this is the fourth case in the territory of the Balkan peninsula after Bor-Majdanpek, Serbia, ${ }^{6}$ Skouries, Greece $^{7}$ and Elatsite, Bulgaria ${ }^{8}$ where the Cu-porphyry style of hydrothermal PGM has been found.

As an alkaline porphyry deposit, the Buchim deposit represents, besides copper, a significant gold resource for Macedonia and fits well into the recently reported elevated levels of PGE, particularly Pd and Pt, described in the Cordillera of British Columbia (Copper Mountain, Galore Creek), Allard Stock, La Plana Mountains, Copper King Mine in the USA, Skouries porphyry deposit in Greece, Elatsite in Bulgaria, ${ }^{9}$ as well as bismuth-selenium derivatives..$^{10}$ In the latest studies, results were ob- 
T. SERAFIMOVSKI et al.: Au-Pd AND Bi-Se BEARING PYRITE AND CHALCOPYRITE FROM THE BUCHIM COPPER MINE ...

Table 1: Quantitative X-ray spectral analyses (EDS) of bismuth and bismuth-selenium minerals in the Buchim deposit (in w/\%), sampling positions shown in Figures 1a to $1 d$.

\begin{tabular}{|c|c|c|c|c|c|c|c|c|c|c|c|}
\hline Element. sample & 1 & 2 & 3 & 4 & 5 & 6 & 7 & 8 & 9 & 10 & 11 \\
\hline $\mathrm{Bi}$ & 99.52 & 80.36 & 80.37 & 54.67 & 55.38 & 64.06 & 64.08 & 41.69 & 42.63 & 41.66 & 80.11 \\
\hline $\mathrm{Pb}$ & 0.18 & - & - & 26.64 & 21.05 & - & - & 33.38 & 30.03 & 30.11 & 2.21 \\
\hline $\mathrm{Cu}$ & - & 0.43 & 0.31 & 0.92 & 6.55 & 14.14 & 13.89 & - & 9.50 & 10.25 & - \\
\hline $\mathrm{Ag}$ & - & - & - & - & - & 2.75 & 2.79 & 4.96 & 0.70 & 0.62 & - \\
\hline $\mathrm{Fe}$ & - & 0.62 & 0.71 & - & - & 0.71 & 0.61 & - & - & - & - \\
\hline $\mathrm{As}$ & - & - & - & - & - & - & - & - & - & - & - \\
\hline $\mathrm{Se}$ & - & - & - & - & - & 1.48 & 2.45 & 0.26 & - & - & 13.41 \\
\hline $\mathrm{Te}$ & - & - & - & - & - & - & - & - & - & - & 1.10 \\
\hline $\mathrm{S}$ & - & 18.59 & 18.61 & 18.42 & 17.71 & 16.74 & 16.15 & 16.84 & 17.20 & 17.36 & 3.10 \\
\hline $\mathrm{S}$ & 99.70 & 100.00 & 100.00 & 100.75 & 100.69 & 99.98 & 99.97 & 97.13 & 100.06 & 100.02 & 99.93 \\
\hline
\end{tabular}

1. Native Bismuth [Bi]; 2. Bismuthinite [ $\left.\left(\mathrm{Bi}_{1.95} \mathrm{Cu}_{0.03} \mathrm{Fe}_{0.05}\right)_{2.04} \mathrm{~S}_{2.95}\right]$; 3. Bismuthinite $\left[\left(\mathrm{Bi}_{1.95} \mathrm{Cu}_{0.02} \mathrm{Fe}_{0.05}\right)_{2.04} \mathrm{~S}_{2.95}\right]$; 4. $\mathrm{Galenobismutite}$ $\left[\left(\mathrm{Pb}_{0.92} \mathrm{Cu}_{0.10}\right)_{1.02} \mathrm{Bi}_{1.87} \mathrm{~S}_{4.10}\right]$; 5. Krupkaite $\left[\mathrm{Cu}_{1.1} \mathrm{~Pb}_{1.09} \mathrm{Bi}_{2.85} \mathrm{~S}_{5.94}\right]$; 6. Emplectite $\left[\mathrm{Bi}_{1.11}\left(\mathrm{Cu}_{0.80} \mathrm{Fe}_{0.04} \mathrm{Ag}_{0.09}\right)_{0.94}\left(\mathrm{~S}_{1.84} \mathrm{Se}_{0.11}\right)_{1.95}\right]$; 7. Emplectite $\left[\mathrm{Bi}_{1.12}\left(\mathrm{Cu}_{0.80} \mathrm{Fe}_{0.04} \mathrm{Ag}_{0.09}\right)_{0.94}\left(\mathrm{~S}_{1.84} \mathrm{Se}_{0.11}\right)_{1.95}\right] ;$ 8. Cosalite $\left[\left(\mathrm{Pb}_{1.55} \mathrm{Ag}_{0.44}\right)_{1.99} \mathrm{Bi}_{1.92}\left(\mathrm{~S}_{5.05} \mathrm{Se}_{0.03}\right)_{5.08}\right.$; 9. Friedrichite $\left[\mathrm{Cu}_{5.02}\right.$ $\left.\left(\mathrm{Pb}_{4.87} \mathrm{Ag}_{0.21}\right)_{5.08} \mathrm{Bi}_{6.85} \mathrm{~S}_{18.01}\right]$; 10. Friedrichite $\left[\mathrm{Cu}_{5.36}\left(\mathrm{~Pb}_{4.84} \mathrm{Ag}_{0.19}\right)_{5.03} \mathrm{Bi}_{6.82} \mathrm{~S}_{17.88}\right] ; 11$. Laitakarite $\left[\left(\mathrm{Bi}_{4.01} \mathrm{P}_{0.10}\right)_{4.11}\left(\mathrm{Se}_{1.78} \mathrm{Te}_{0.09} \mathrm{~S}_{1.02}\right)_{2.89}\right]$

tained for Au-Pd-bearing pyrite and chalcopyrite as well as $\mathrm{Bi}-\mathrm{Se} \pm \mathrm{Au} \pm \mathrm{Ag} \pm \mathrm{Te}$ minerals, which are the subject of this study.

\section{EXPERIMENTAL PART}

Field sampling took place within the boundaries of the active Buchim open-pit mine. Samples were taken from the Central ore body, between $580 \mathrm{~m}$ and $540 \mathrm{~m}$, for microscopic and microprobe studies. In total, 40 ore samples were studied under a Zeiss Axiolab Pol polarised reflected-light microscope equipped with a ZEISS MC 80 DX (Databack D4) analogue camera and stateof-the-art LEICA DMP 4500 polarised reflected-light microscope equipped with a LEICA DFC 450 digital camera (at magnifications in the range of $100 \times$ to $630 \times$ ) in the optical laboratory of the Faculty of Natural and Technical Sciences, University "Goce Delčev"-Štip, R. Macedonia. Some of the most representative microscope photographs are given in Figure 1.
Quantitative elemental analyses of the most interesting samples were performed in two stages. First, an older JEOL Superprobe 733 was used with the following standards: for Bi-synthetic $\mathrm{Bi}_{3} \mathrm{~S}_{3}$; for $\mathrm{Ag}$-synthetic $\mathrm{Ag}$; for $\mathrm{Cu}, \mathrm{Fe}$ and S-synthetic $\mathrm{CuFeS}_{2}$; for Se-synthetic PbSe; for $\mathrm{Pb}$-synthetic $\mathrm{PbS}$; for As-chemically analysed and checked for homogeneity FeAsS; $I=0.8 \mathrm{~A}$ and $U=25 \mathrm{kV}$. At the more advanced stage of the study, we used a JEOL JXA-8200 Electron Probe Micro-Analyser WD/ED Combined Microanalyzer (equipped with a SEand BSE-detector, 5-WDS crystal spectrometer and an EDS analyser) in the analytical facilities at the Institute of Geochemistry and Petrology, ETH-Zurich, Switzerland. The selected electron-beam conditions were a beam current of $20 \mathrm{nA}$ at an acceleration voltage of $15 \mathrm{kV}$. The $\mathrm{X}$-ray studies of particular minerals were carried out using X-ray diffraction (TUR-M-60, camera RKD-57, Cu, Ni 30 hours). Besides the spectroscopic analysis of the elements, electron microphotographs were taken.

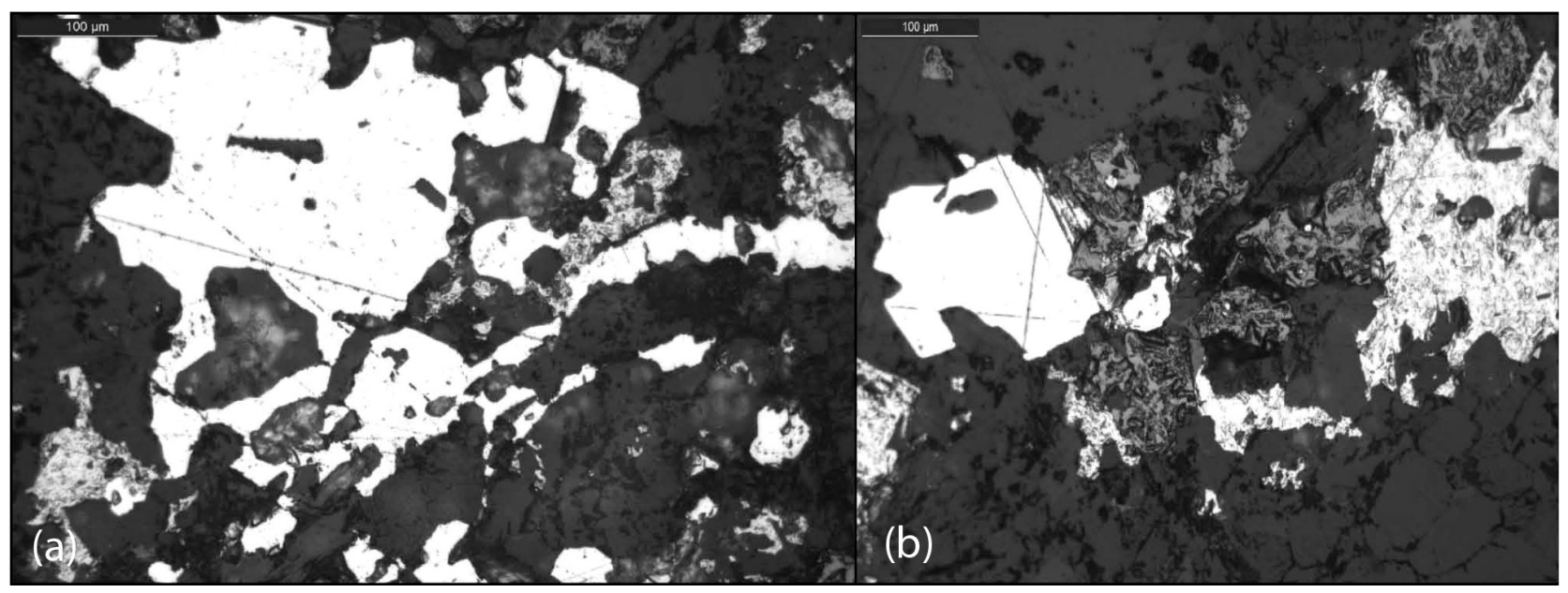

Figure 1: Microscope photographs of: a) microscope detail of massive/blocky pyrite (light yellow) associated with some chalcopyrite (darker yellow) within rock matrixand b) representative chalcopyrite-pyrite-magnetite association within corroded quartz vein 


\section{RESULTS}

In following review, we present the most important features of the particular $\mathrm{Bi}, \mathrm{Se}$ and mixtures of rare Bi-Se sulphosalt mineral phases, then we concentrate on the $\mathrm{Au}, \mathrm{Ag}$ and $\mathrm{Pd}$ phases in the chalcopyrite and pyrite. Within the quartz-pyrite-chalcopyrite paragenesis, bismuth and bismuth-selenium minerals occur in the following order: quartz-pyrite-chalcopyrite-bismuthinite-galenobismutite-krupkaite-friedrichite-emplectite-la itakarite-native bismuth (Figure 2, Table 1).

Preliminary microscope and microprobe investigations in our "quest" for rare minerals within the Buchim porphyry copper deposit determined two main mineral assemblages: magnetite-pyrite-chalcopyrite (Mt-Py-Cp) and pyrite-chalcopyrite (Py-Cp) as the major hosts of $\mathrm{Au}$ and Pd.

The studied pyrite grains are of four different generations (pyrite micro-disseminations, network-like veins of quartz-pyrite-chalcopyrite-magnetite, pyrite veinlets and massive/blocky pyrite) and increased concentrations of $\mathrm{Au}$ and Pd were determined in so-called block pyrites or massive pyrite with coarse crystallinity and grains up to $0.5 \mathrm{~mm}$ (Figure 3). The Au-Pd phase occurs as a separate mineral phase distinguished by a special color (gull grey to pink grey; Figure 3). That mineral phase mostly corresponds to pyrite (Table 2), but as can be seen from the table, increased gold $(7.746 \%$ Au, Table 2, analysis 10) and palladium (6.784\% Pd, Table 2, analysis 11) concentrations are directly associated with decreased concentrations of iron and sulfur as the major constituents of pyrite.

\section{DISCUSSION}

The determined mineral associations in the Buchim deposit are comparable with other deposits of the same type. $2,5,7,11,12$ In fact, the similarity is related to the major sulphide and sulphosalt minerals and mineral phases as well as in regards to the rare minerals with the significant participation of gold, silver, tellurium, selenium, bismuth, platinum, and palladium. The pyrite and chalcopyrite are the most common ore minerals within the

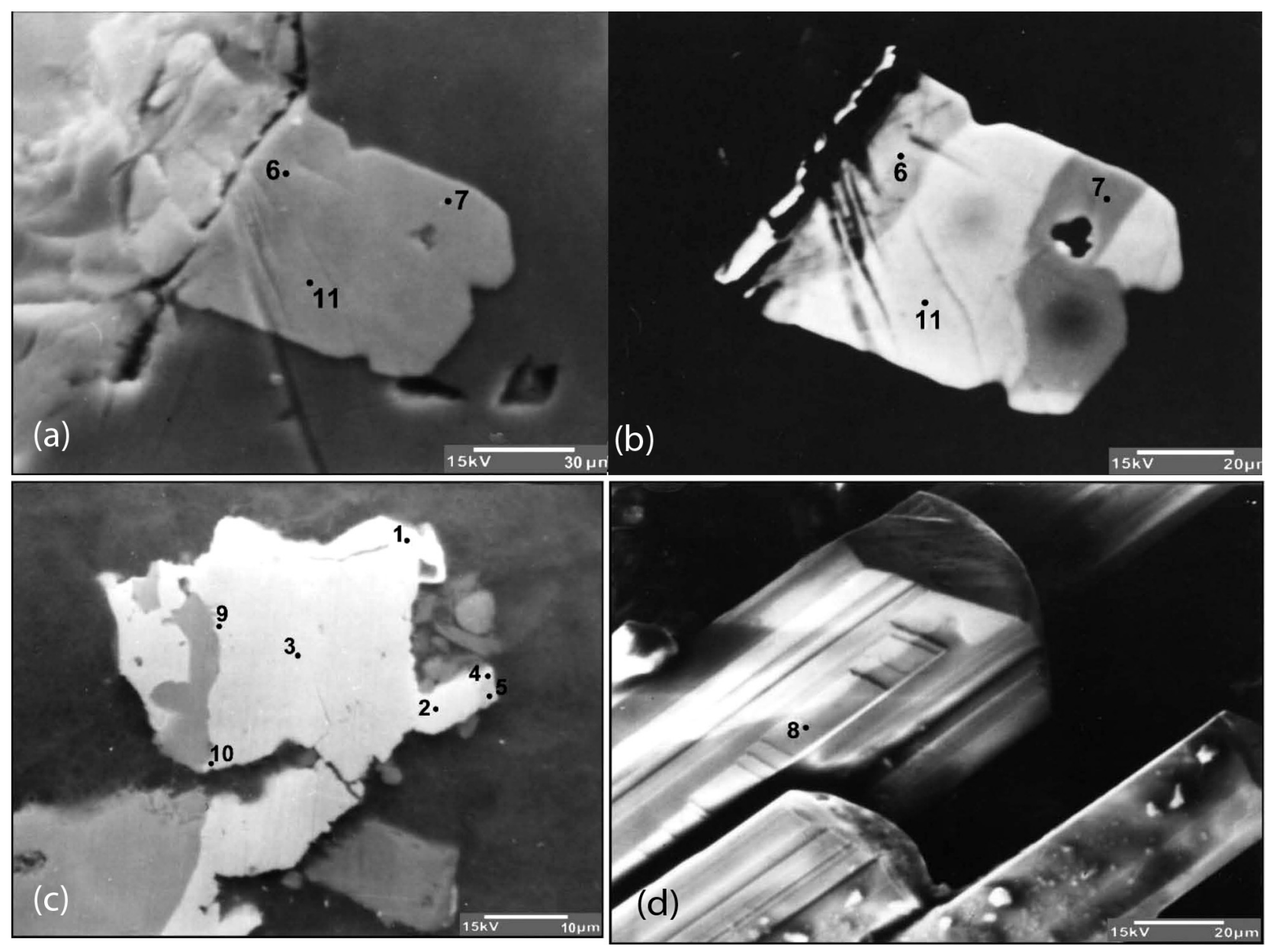

Figure 2: Bismuth-selenium mineral paragenesis in the Buchim porphyry copper deposit: a) laitakarite-emplectite agregate (gray-white) in hydrothermally altered rock (dark), backscattered electrons, b) laitakarite (white), emplectite (gray), COMPO (when backscattered electron signal (BSE) in the scanning electron microscope (SEM) has been used for an investigation of a specimen surface composition), c) bismuthinite (white) along chalcopyrite (gray) in hydrothermally altered rock (dark), COMPO, d) illustration of cosalite crystal representative morphological forms, scanning-electron photograph 

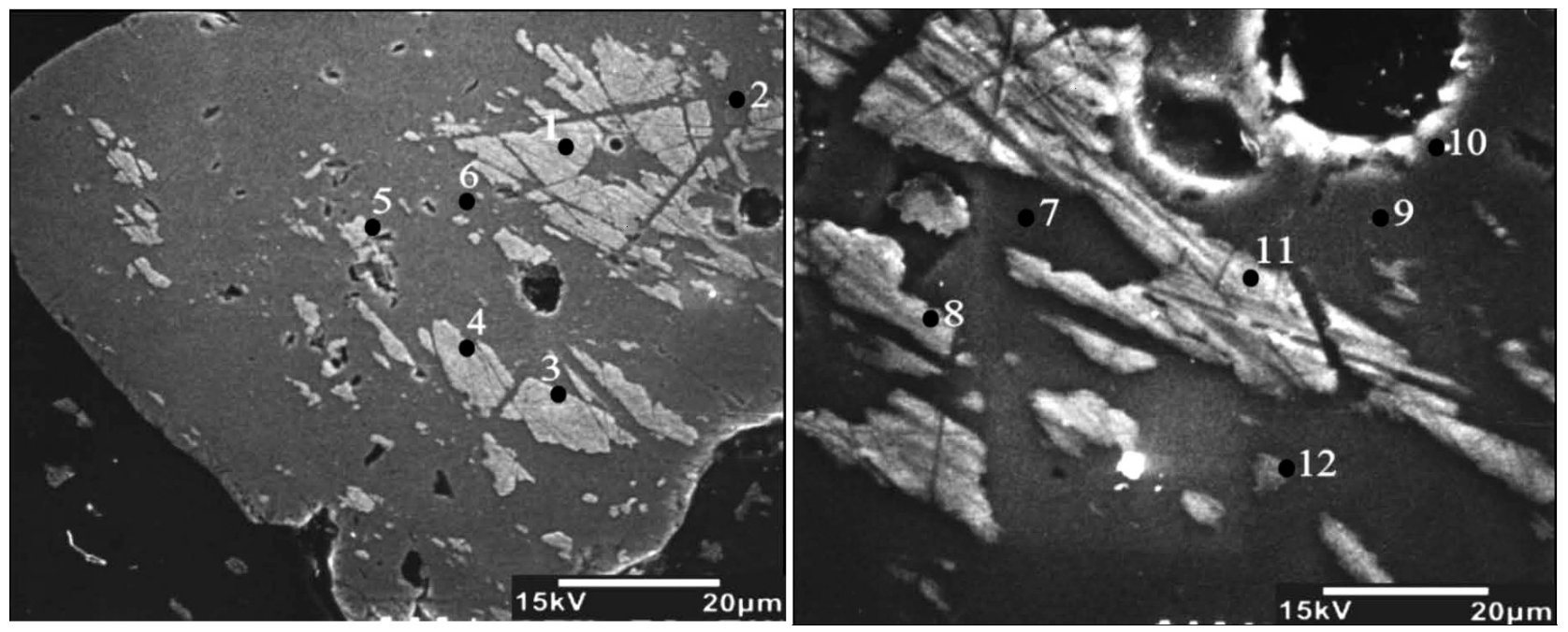

Figure 3: Electron microprobe photographs of pyrites (dark grey) with Au-Pd admixtures (light grey), from the Buchim porhyry copper deposit, Central Part ore body, with analysis points: a) pyrite grain with Au-Pd admixtures, b) detail, c) microscope detail of massive/blocky pyrite (light yellow) associated with some chalcopyrite (darker yellow) within rock matrix

Table 2: Quantitative X-ray spectral analyses of pyrite in the Buchim deposit (w/\%)

\begin{tabular}{|c|c|c|c|c|c|c|c|c|c|c|c|c|}
\hline Analysis & 1 & 2 & 3 & 4 & 5 & 6 & 7 & 8 & 9 & 10 & 11 & 12 \\
\hline $\mathrm{Au}(\%)$ & 6.979 & 0.21 & 7.627 & 6.512 & 0.12 & 7.54 & 0.22 & 0.027 & 0.1 & 7.746 & 6.47 & 0.033 \\
\hline $\mathrm{Fe}(\%)$ & 39.228 & 43.636 & 40.575 & 39.976 & 45.458 & 43.556 & 43.854 & 45.438 & 45.123 & 39.177 & 38.932 & 45.531 \\
\hline $\mathrm{S}(\%)$ & 44.438 & 53.503 & 47.352 & 44.398 & 53.534 & 47.342 & 52.668 & 51.818 & 53.265 & 46.169 & 45.452 & 53.926 \\
\hline $\mathrm{Cu}(\%)$ & 0 & 0 & 0.01 & 0.022 & 0.062 & 0.012 & 0 & 0 & 0.02 & 0.034 & 0 & 0.024 \\
\hline $\mathrm{As}(\%)$ & 0.157 & 0 & 0.019 & 0.684 & 0.141 & 0.02 & 0.02 & 0.761 & 0 & 0.028 & 0.042 & 0.157 \\
\hline $\mathrm{Ag}(\%)$ & 0 & 0 & 0.21 & 0 & 0 & 0.73 & 0.04 & 0 & 0.02 & 0 & 0 & 0 \\
\hline $\mathrm{Pd}(\%)$ & 6.33 & 0.01 & 1.25 & 5.65 & 1.23 & 0.04 & 0 & 2.34 & 0 & 6.02 & 6.784 & 0.28 \\
\hline $\mathrm{Ge}(\%)$ & 0.31 & 0.35 & - & - & - & 0.21 & & & & 0.25 & 0.38 & \\
\hline $\mathrm{Zn}(\%)$ & 0.22 & & - & - & - & & 0.37 & & & 0.26 & 0.35 & \\
\hline $\mathrm{V}(\%)$ & 0.33 & 0.25 & 0.27 & 0.21 & - & 0.22 & 0.41 & & & 0.21 & 0.32 & \\
\hline $\mathrm{Ni}(\%)$ & 0.24 & 0.47 & - & & - & 0.21 & 0.54 & & & 0.15 & 0.28 & \\
\hline $\mathrm{Se}(\%)$ & - & - & 0.74 & 0.52 & - & - & & & & & & \\
\hline $\mathrm{Bi}(\%)$ & - & - & 0.48 & 0.65 & - & - & & & & & & \\
\hline $\mathrm{Te}(\%)$ & - & - & 0.35 & 0.39 & - & - & 0.21 & & & & & \\
\hline $\mathrm{L} \mathrm{sum}$ & 98.232 & 98.429 & 98.883 & 99.012 & 100.545 & 99.88 & 98.332 & 100.384 & 98.528 & 100.044 & 99.01 & 99.951 \\
\hline
\end{tabular}

deposit and constitute the major sulphide paragenesis in the Buchim deposit, while the latest mineralogical studies have discovered numerous new mineral phases of bismuth, Bi-Se, Cu-Bi-As-S, Au-Ag-Pt-Pd and Au-Pd.

Bismuth-selenium mineralisation in the Buchim porphyry copper deposit can be considered as a typomorph for gold-bearing types of endogenous mineralisation. Quartz-pyrite-chalcopyrite paragenesis successive order of minerals where bismuth and bismuth-selenium minerals occur as bismuthinite-galenobismutite-krupkaitefriedrichite-emplectite-laitakarite-native bismuth shows that according to the time of their deposition, they engaged substantial amounts of copper and iron. Copper is present in bismuthinite in the range 0.31-1.82 w/\% Cu, in galenobismutite $0.92 \% w / \% \mathrm{Cu}$, in krupkaite $0.92-6.28 w / \% \mathrm{Cu}$, friedrichite $9.50-10.25 w / \% \mathrm{Cu}$ and emplectite $6.55-14.14 w / \% \mathrm{Cu}$. The iron distribution is more homogenous and ranges from 0.61 to $1.90 w / \% \mathrm{Fe}$. Selenium is not representative of the initial part of the paragenesis; it scarcely occurs in krupkaite (1.12 $w / \% \mathrm{Se})$, emplectite $(1.85-2.45 w / \% \mathrm{Se})$, while the most abundant is in laitakarite $(13.5 \mathrm{w} / \% \mathrm{Se})$.

Increased concentrations of copper and iron in the bismuth-selenium minerals are probably closely related to the intense corrosion alterations in the chalcopyrite. Those alterations exemplify the hydrothermal metamorphism of chalcopyrite. One fraction of selenium could be attributed to corrosion processes and alterations of chalcopyrite, but during the deposition of laitakarite, there was probably a yield of selenium by hydrothermal solutions. In the second paragenesis, which also carries certain amounts of bismuth, significant concentrations of silver (up to $4.96 w / \% \mathrm{Ag}$ ) occur, as well as a small fraction of selenium $(0.26 w / \% \mathrm{Se})$. The determined existence of bismuth-selenium mineralisation within the Buchim ore deposit gave us an insight into a more detailed geological-genetic model of the deposit, which can be used in the study and exploration of similar deposits, analo- 
gous to the Buchim deposit. From an economic point of view, it is a necessary to study the quantitative distribution of bismuth, selenium and silver in the entire deposit and to make an effort to foresee possibilities for their valorization.

Characteristic of the Mt-Py-Cp assemblage (earlier and high-temperature) is the geochemical association $\mathrm{Fe}-\mathrm{Cu}-\mathrm{Ni}$, Co-As-O-S+Au, Ag and $\mathrm{Pd}$, with magnetite, chalcopyrite, pyrite, cobaltite, $\mathrm{Ni}-\mathrm{Co}-\mathrm{Fe}$-sulfides and native $\mathrm{Au}$ (subordinate and rare). $\mathrm{Pd}$ is included in the structure of the main, subordinate and rare minerals.

Later enrichment of the hydrothermal fluids with $\mathrm{Cu}$, $\mathrm{Bi}, \mathrm{Se}, \mathrm{Te}, \mathrm{Pb}, \mathrm{As}, \mathrm{Au}$ and $\mathrm{Ag}$ led to the formation of $\mathrm{Py}-\mathrm{Cp}$ assemblages overprinting the Mt-Py-Cp aggregates. New minerals were formed, partly as a result of the inclusion of the elements in situ: aikinite, bismuthinite, friedrichite, wittichenite, soucekite, emplectite, paderaite, merenskyite, michenerite (Serafimovski et al. 2006), other Pd-Bi-Te phases, tennantite (including Pd-, $\mathrm{Co}-$ and Ni-bearing), Ni-Co pyrite, Ni-Te phases, $\mathrm{Bi}-\mathrm{Pb}-\mathrm{Ag}-\mathrm{S}$ phases, $\mathrm{Cu}-\mathrm{Fe}-\mathrm{Bi}-\mathrm{S}$ phases, galena, clausthalite, sphalerite, native gold, electrum and (in the uppermost levels) enargite, luzonite and pearceite. ${ }^{5}$

The Au-Pd association was determined within the pyrite and chalcopyrite of the major ore-bearing phase in the central ore body in the Buchim mine. It should be stressed that this Au-Pd association occupies certain levels $(580-540 \mathrm{~m})$ within the Buchim open pit. There, ore-bearing pyrite and chalcopyrite are found in association with magnetite and are usually massive and coarse grained.

The relationship between the concentrations of gold, palladium and arsenic in the pyrite and chalcopyrite from the Buchim deposit show a high degree of geochemical correlation. ${ }^{13}$ This probably points to the wide range of physicochemical conditions and the interplay between the magmatic and the hydrothermal processes during the formation of the deposit. The addition of volatiles associated with these magma mixing processes was responsible for the magmatic-hydrothermal $\mathrm{Cu}-\mathrm{Au}$ mineralization in the porphyry intrusion or in the surrounding gneiss host rocks (gneiss). Undoubtedly, REE analyses indicated an oxidizing environment $\left(\mathrm{Ce} / \mathrm{Ce}^{*}\right)$, while the negative Eu-anomaly $\left(\mathrm{Eu} / \mathrm{Eu}^{*}\right)$ points to an earlier crystallization of plagioclase (G. Tasev and T. Serafimovski; ${ }^{14} \mathrm{~S}$. Lehman et al. ${ }^{15}$ ), while high ratios of some trace elements such as $\mathrm{Sr} / \mathrm{Y}$ and $\mathrm{La} / \mathrm{Yb}$ may be an indicator for a high pressure and/or strongly hydrous fractionation, as suggested by M. Kolb et al., ${ }^{16}$ which all together with the magmatic fluids of the hydrothermal system and certain participation of meteoric portion in the Buchim ore deposit may be a strong control of the Pd concentration in the ore. The relatively lower Pd content, compared to some other similar systems (M. Economou-Eliopoulos and G. D. Eliopoulos), ${ }^{17}$ with increasing Te, As, $\mathrm{Pb}$ and $\mathrm{Zn}$ content most probably indicates that the Pd distribution in this particular porphyry copper system is effected by the evolution of the magma-hydrothermal system (P. Frei). ${ }^{18}$ The palladium content in the Buchim porphyry copper deposit may be related to an early vein-type $\mathrm{Cu}$ mineralization or it was redistributed and concentrated by leaching (due to supergene leaching under oxidizing conditions) from early-stage stockwork mineralization. The relatively low Pd-enrichment only in certain samples from the Buchim deposit, may indicate that an oxidation process, by leaching from an early-stage stockwork mineralization could have played a certain role in the precious-metal concentration. However, the fact that Pd-enrichments within the Buchim ore deposit are hosted predominantly as inclusions within sulphides is a strong evidence that the Pd in this deposit is part of the same mineralising event as the $\mathrm{Cu}$ and $\mathrm{Au}$.

Increased concentration of $\mathrm{Au}$ and $\mathrm{Pd}$ in practice means that there is a substitution of major pyrite constituents by gold and palladium. The fact that gold and palladium form such a mixture in the main mineral phase in pyrite and chalcopyrite equally (temperatures around $250{ }^{\circ} \mathrm{C}$ ) and their absence in the later phases of the ore-bearing process could indicate the stabilisation of the crystal lattice of the pyrite in the later evolution of the process.

In chalcopyrite, the Au-Pd concentrations are probably related to the mixed mineral phases that we were unable to fully determine, but with the noted presence of Au-Pd in chalcopyrite, we have confirmed that there are numerous mineral phases, such as Bi-Se minerals (laitakarite, friedrichite, cosalite), already determined previously by T. Serafimovski ${ }^{11}$ and T. Serafimovski et al. ${ }^{4}$

\section{CONCLUSIONS}

The scanning electron microscopy and spectroscopy studies of the ore samples from the Buchim porphyry copper deposit determined several mineral groups with representative mineral paragenesis, where interesting rare mineral phases of $\mathrm{Cu}-\mathrm{Bi}-\mathrm{Se}-\mathrm{Te}$ associations and Au-Pd metals were determined. The two main mineral paragenesis, quartz-pyrite-chalcopyrite, have been defined as major bearers of $\mathrm{Bi}-\mathrm{Se}$-Te rare mineral phases where bismuthinite, galenobismutite, krupkaite, friedrichite, emplectite, laitakarite, native bismuth and magnetite-pyrite-chalcopyrite predominated as the bearer of the Au-Pd mineral phases.

The gold content in the Buchim pyrite is within the range $0.027-7.746 \% \mathrm{Au}$, while the palladium content is within the range $0.040-6.784 \% \mathrm{Pd}$, and they are related to the special mixture mineral phases characterised by a gull gray colour. Increased concentrations of $\mathrm{Au}-\mathrm{Pd}$ in chalcopyrite (6.335-9.095 \% $\mathrm{Au}$ and 1.33-8.11\% Pd) are related to the massive medium-to-high temperature chalcopyrite, which constitutes the major ore phase within the Buchim deposit. For more detailed definition of the PGE, additional studies are needed. 


\section{REFERENCES}

${ }^{1}$ T. Serafimovski, V. Cifliganec, S. Jankovic, B. Boev, Genetic Model of the Buchim Porphyry Copper Deposit, Republic of Macedonia Proceedings of the Annual Meeting, UNESCO-IGCP Project 356, Vol. 1, Sofija 1996, 63-75

${ }^{2}$ V. Čifliganec, Copper Mineralization in the Republic of Macedonia, 1st ed., Universitet "Sv. Kiril i Metodij", Skopje 1993, 303

${ }^{3}$ M. Pavičević, S. Rakić, Study of occurence of gold, silver and other rare elements in ores from the Central ore body, Buchim, ULEMA, Belgrade 1983, 202

${ }^{4}$ T. Serafimovski, G. Tasev, P. Lazarov, Au-Ag-Te-Bi-Se minerals associated with porphyry copper mineralization in the Buchim copper mine, R. Macedonia. Au-Ag-Te-Se deposits IGCP-486, Field Workshop, Izmir 2006, 154-158

${ }^{5}$ R. Petrunov, T. Serafimovski, P. Dragov, New finding of PGE-mineralisation in porphyry-copper environment-the Buchim deposit, Macedonia: preliminary microscope and microprobe data, ABCD-GEODE 2001 Workshop Vata Bai, Romania 2001, 79-80

${ }^{6} \mathrm{~S}$. Janković, Ore deposit of Serbia, Faculty of Mining and Geology, Belgrade 1990, 765

${ }^{7}$ M. Tarkian, D. G. Eliopoulos, M. Economou-Eliopoulos, Mineralogy of precious metals in the Skouries porphyry copper deposit, N. Greece, Neues Jahrbuch fur Mineralogie Abhandlungen, 1991, 529-537

${ }^{8}$ R. Petrunov, P. Dragov, G. Ignatov, H. Heykov, Ts. Iliev, N Vassileva, V. Tzatzov, S. Djunakov, K. Doncheva, Hydrothermal PGE-mineralization in the Elatsite porphyry-copper deposit (Sredna Gora metallogenic zone, Bulgaria), Comptes Rendu Academie Bulg. Sci, 45/4 (1992) 37-40

${ }^{9}$ M. Economou-Eliopoulos, Platinum-group elements (PGE) in various geotectonic settings: Opportunities and risks, Hellenic Journal of Geosciences, 45 (2010) 65-82

${ }^{10}$ C. P. Voudouris, G. P. Spry, C. Mavrogonatos, G. A. Sakellaris, K. S. Bristol, V. Melfos, P. A. Fornadel, Bismuthinite derivatives, lillianite homologues, and bismuth sulfotellurides as indicators of gold mineralization in the Stanos shear-zone related deposit, Chalkidiki, Northern Greece, The Canadian Mineralogist, 51 (2013), 119-142, doi:10.3749/canmin.51.1.119
${ }^{11}$ T. Serafimovski, Structural-metallogenic features of the Lece-Chalkidiki zone: types of mineral deposit and distribution. Special Issue No. 2. University of St Cyril and Methodius, Stip 1993, 325

${ }^{12}$ V. A. Volkov, T. Serafimovski, V. Stefanova, A. A. Sidorov, Formation Mechanism of Dwarfish Cu-Au Porphyry Deposits of Macedonia, Doklady Earth Sciences, 431/2 (2010), 429-434

${ }^{13} \mathrm{~K}$. Pockov, Geochemical types of pyrites in the porphyry copper deposit Buchim. Master thesis, Faculty of Mining and Geology, Štip 1997, 125

${ }^{14}$ G. Tasev, T. Serafimovski, REE in some Tertiary volcanic complexes in the Republic of Macedonia. Geologica Macedonica, 23 (2009), $17-25$

${ }^{15}$ S. Lehmann, J. Barcikowski, A. von Quadt, D. Gallhofer, I. Peytcheva, C. A. Heinrich, T. Serafimovski, Geochronology, geochemistry and isotope tracing of the Oligocene magmatism of the Buchim-Damjan-Borov Dol ore district: Implications for timing, duration and source of the magmatism, Lithos, 180-181 (2013), 216-233

${ }^{16}$ M. Kolb, A. von Quadt, I. Peytcheva, C. A. Heinrich, S. J. Fowler, V. Cvetkovic, Adakite-like and normal arc magmas: distinct fractionation paths in the East Serbian segment of the Balkan-Carpathian Arc. Journal of Petrology 1-31 (2012), doi:10.1093/petrology/ egs072

${ }^{17}$ M. Economou-Eliopoulos, G. D. Eliopoulos, Palladium, platinum and gold concentration in porphyry copper systems of Greece and their genetic significance. Ore Geology Reviews, 16 (2000) 59-70

${ }^{18}$ P. Frei, Evolution of mineralizing fluid in the porphyry copper system of the Skouries deposit, northeast Chalkidiki -Greece: evidence from combined $\mathrm{Pb}-\mathrm{Sr}$ and stable isotope data,Econ. Geol. 90 (1995), $746-762$ 